\title{
Keputusan pemustaka dalam penelusuran informasi di Perpustakaan Balai Penelitian Tanaman Rempah dan Obat
}

\author{
Rushendi \\ Balai Penelitian Tanaman Rempah dan Obat, Kementrian Pertanian \\ Kampus Penelitian Pertanian Cimanggu, Jl. Tentara Pelajar No. 3 Bogor 16114, Indonesia \\ E-mail: rushendi@pertanian.go.id
}

Received: November 2017; Accepted: Mei 2018; Published: Juni 2018

\begin{abstract}
The needs of library information need to be met to complete the information needs of the library users who generally have a variety of reasons to perform activities in accordance with their purpose. Information retrieval activity is one of the main activities of the library users at the library of the Research Institute for Spices and Medicinal Herbs (RISMH) to find the source of literature through the Online Public Access Catalog (OPAC) facility. The purpose of the research was to determine the decision of the user in searching for information. The study was conducted from November to December 2017, with materials obtained from the library literature search 2015 -2017 results form. The study used the quantitative descriptive method, while the observed variables were: searching users; sources of the required information; subjects needed, and the relationship of the user with the library material searched. Data were analyzed descriptively. The result of the study showed the dominant user searching for information was the researcher; source of information required was documentation, and subject/commodity needed by the user which was medicinal plants. There is a correlation between the researcher's decision and the searching of journal literature and documentation; student decisions by searching books, journals, and documentation; as well as the general/private user's decisions with book search and documentation. The information retrieval service at the Balittro Library needs to be improved by linking the online search database with the Balittro website so it can increase the number of online collections.
\end{abstract}

Keywords: Decision; Searching for information; Users

\begin{abstract}
Abstrak
Kebutuhan informasi perpustakaan perlu dipenuhi untuk melengkapi kebutuhan informasi para pemustaka, dimana pemustaka yang berkunjung umumnya memiliki berbagai alasan melakukan kegiatan sesuai dengan tujuannya. Kegiatan penelusuran informasi merupakan salah satu kegiatan utama pemustaka di Perpustakaan Balai Penelitian Tanaman Rempah dan Obat (Balittro) dalam menemukan sumber literatur melalui fasilitas Online Public Access Catalogue (OPAC). Tujuan penelitian ini yaitu untuk mengetahui keputusan pemustaka dalam penelusuran informasi. Penelitian ini dilaksanakan pada bulan November sampai dengan Desember 2017, dengan bahan diperoleh dari formulir hasil penelusuran bahan pustaka pemustaka tahun 2015-2017. Metode penelitian ini menggunakan metode deskriptif kuantitatif, sedangkan variabel yang diamati: pemustaka menelusur informasi; sumber informasi yang diperlukan; subjek yang diperlukan, dan hubungan pemustaka dengan bahan pustaka yang ditelusur. Data dianalisis secara deskriptif. Hasil penelitian menunjukkan pemustaka dominan dalam menelusur informasi diantaranya yaitu: peneliti; sumber informasi yang diperlukan yaitu dokumentasi (laporan penelitian, prosiding, monograf, dll); dan subjek/komoditas yang diperlukan pemustaka yaitu tanaman obat. Terdapat hubungan antara keputusan peneliti dengan penelusuran bahan pustaka jurnal dan dokumentasi; keputusan mahasiswa dengan penelusuran buku, jurnal dan dokumentasi; serta keputusan pemustaka umum/swasta dengan penelusuran buku dan dokumentasi. Pelayanan penelusuran informasi di Perpustakaan Balittro perlu ditingkatkan dengan menghubungkan database penelusuran online dengan website Balittro sehingga bisa bertambah jumlah koleksi onlinenya.
\end{abstract}

Kata Kunci: Keputusan; Penelusuran informasi; Pemustaka 


\section{PENDAHULUAN}

Perkembangan dunia perpustakaan di tanah air sangat cepat berkembang. Dewasa ini sebagai efek perkembangan dan kemajuan-kemajuan di bidang ilmu pengetahuan dan teknologi, permintaan informasi dari para pemakai jasa layanan perpustakaan semakin meningkat (Arma \& Nelisa, 2013).

Pada era globalisasi, informasi telah berkembang sangat pesat dan menjadi kebutuhan utama manusia. Menurut Sulistiyo-Basuki dalam Arma dan Nelisa (2013) perpustakaan sebagai sarana penyediaan informasi, perpustakaan dituntut untuk menyediakan berbagai macam informasi yang sesuai dengan kebutuhan pemakai dan sesuai dengan perkembangan ilmu pengetahuan. Perpustakaan merupakan tempat pencarian dan pengumpulan informasi, oleh sebab itu, perpustakaan semestinya harus menyediakan koleksi yang lengkap dan baru sesuai minat atau kebutuhan pemustaka.

Menurut Arma dan Nelisa (2013) informasi memegang peranan yang semakin besar dalam perkembangan ilmu pengetahuan. Informasi meningkatkan efisiensi ilmu pengetahuan yang merupakan alat produktif pada masyarakat modern. Ilmu pengetahuan dan sistem pemencaran pengetahuan berjalan dalam skala misal, namun mentalitas pemakaian dalam memanfaatkan informasi masih mencerminkan tingkat awal pengembangan ilmu pengetahuan. Kini dengan banyaknya unit informasi serta berkembangnya teknologi informasi, pengumpulan dan pengolahan informasi dilakukan dari berbagai sumber, sementara pemakai tinggal memanfaatkannya.
Perpustakaan saat ini telah menjadi wadah pusat informasi, sumber ilmu pengetahuan, penelitian, rekreasi, pelestarian budaya bangsa, dan memberikan berbagai layanan jasa lainnya (Jurnalista \& Hermintoyo, 2016). Menurut pernyataan Sutarno dalam Riadi (2012) perpustakaan adalah mencakup suatu ruangan, bagian dari gedung/bangunan atau gedung tersendiri yang berisi buku-buku koleksi, yang diatur dan disusun demikian rupa, sehingga mudah untuk dicari dan dipergunakan apabila sewaktu-waktu diperlukan oleh pembaca. Definisi lainnya dikemukakan oleh Lasa (2007) dalam Rasdanelis (2016) bahwa perpustakaan adalah kumpulan atau bangunan fisik sebagai tempat buku dikumpulkan dan disusun menurut sistem tertentu atau keperluan pemakai. Dari kedua pengertian diatas, dapat dinyatakan bahwa perpustakaan adalah tempat untuk mengembangkan informasi dan pengetahuan yang dikelola oleh suatu lembaga, berisi kumpulan buku-buku koleksi yang dikelola secara rapi dan teratur.

Menurut Sulistiyo-Basuki dalam Arma dan Nelisa (2013) perpustakaan khusus adalah perpustakaan yang didirikan suatu lembaga tertentu untuk mendukung visi dan misi suatu instansi atau lembaga tersebut dan berfungsi sebagai pusat informasi. Ciri-ciri perpustakaan khusus: 1) memiliki buku yang terbatas pada satu atau beberapa disiplin ilmu saja; 2) keanggotaan perpustakaan terbatas pada sejumlah anggota yang ditentukan oleh kebijakan perpustakaan atau kebijakan badan induk tempat perpustakaan yang tersebut; 3) peran utama pustakawan ialah melakukan penelitian kepustakaan untuk anggota; 4) tekanan koleksi bukan pada buku 
melainkan pada majalah, pamflet, paten, laporan penelitian, abstrak, atau indeks karena jenis tersebut umumnya informasinya lebih mutakhir dibandingkan buku; dan 5) jasa yang diberikan lebih mengarah kepada minat anggota perorangan.

Menurut pernyataan Yusup dalam Arma dan Nelisa (2013), perpustakaan disebut berfungsi sebagai pusat sumber infomasi karena memenuhi ciri-ciri: (1) tempat dihimpunnya berbagai jenis sumber informasi; (2) tempat diolahnya berbagai macam sumber informasi; (3) tempat penyebaran informasi kepada masyarakat; (4) perpustakaan sebagai tempat lahirnya informasi, misalnya informasi tentang pengembangan perpustakaan; (5) tempat pemeliharaan dan pelestarian segala jenis informasi; dan (6) perpustakaan sebagai tempat pewarisan budaya bangsa.

Kebutuhan informasi di perpustakaan perlu dipenuhi untuk melengkapi kebutuhan informasi pemustaka. Pemustaka merupakan istilah yang biasa digunakan untuk pengunjung perpustakaan perseorangan, kelompok orang, masyarakat, atau lembaga yang memanfaatkan fasilitas layanan perpustakaan (Perpusnas, 2015). Keberadaan perpustakaan di tengah-tengah masyarakat dirasakan sangat penting. Hal ini disebabkan karena perpustakaan merupakan tempat mencari ilmu, mengumpulkan informasi dan untuk mengikuti perkembangan zaman. Menurut Sutarno dalam Riadi (2012) perpustakaan salah satunya menyediakan dan menyajikan informasi seluruh koleksinya diberdayakan dan untuk siap dipergunakanpemakainya.

Pemustaka yang datang pada perpustakaan umumnya memiliki berbagai alasan dan akan melakukan kegiatan yang ada pada perpustakaan sesuai dengan tujuannya. Setiap pemustaka berkunjung ke perpustakaan memiliki tujuan yang berbeda-beda. Ada yang hanya sekedar mencari hiburan, ada yang menikmati layanan yang disediakan oleh perpustakaan, bahkan ada yang mencari informasi untuk pemenuhan kebutuhan informasinya. Menurut Gunarti dalam Fransisca (2008) menjelaskan bahwa maksud pemustaka berkunjung ke perpustakaan adalah kunjungan "ilmiah" untuk mencari informasi yang diperlukan, dan karena ada dorongan lainnya atau hanya melepaskan lelahsambil membaca koran yang belum sempat terbaca, serta hanya sekedar ingin melihat-lihat, dll.

Layanan merupakan salah satu subsistem perpustakaan yang berhubungan langsung dengan pengguna (user), baik yang langsung maupun tidak langsung datang ke perpustakaan. Layanan merupakan ujung tombak dan sekaligus gambaran kualitas suatu perpustakaan. Kinerja suatu perpustakaan tercermin dari tingkat dan kualitas layanan yang diberikan. Layanan yang disediakan suatu perpustakaan bergantung pada jenis perpustakaan, yang pada umumnya dikelompokkan menjadi perpustakaan khusus, umum, sekolah, perguruan tinggi, dan perpustakaan nasional. Pengelompokan pada perpustakaan khusus lebih disebabkan oleh kekhususan organisasi, tingkat atau kelompok pengguna yang dilayani, dan mayoritas subjek disiplin ilmu koleksinya. Pada perpustakaan khusus, layanan lebih bertujuan untuk memenuhi kebutuhan informasi para pengguna di lembaga induknya, menyimpan dan menemukan kembali informasi serta menyebarkannya secara cepat dan tepat kepada para staf, 
dan membantu pimpinan memperoleh bahan untuk pengambilan keputusan (Kusmayadi \& Andriaty, 2006).

Pelayanan yang disediakan pada Perpustakaan khusus Balai Penelitian Tanaman Rempah dan Obat (Balittro) terdiri dari : (a) pelayanan sirkulasi dengan sistem tertutup (closed access) bagi pemustaka di luarlingkup Balittro, yang hanya boleh membaca di tempatserta tidak diperkenankan mengambil sendiri bahan pustaka; dan sistem terbuka (open access) diperuntukan bagi para peneliti dan karyawan lingkup Balittro, mereka dapat memilih sendiri bahan pustaka/literatur yang diperlukan, juga bisa meminta bantuan petugas pustakawan bila ada kesulitan, dan bisa meminjam bahan pustaka tersebut dengan mengisi bon peminjaman terlebih dahulu;dan (b) pelayanan penelusuran terdiri atas penelusuran manual (bibliografibibliografi khusus tanaman rempah, obat, atsiri, dll, yang telah disediakan); dan penelusuran elektronik (Online Public Access Cataloguedan jurnal elektronik). MenurutWahyuni (2015) kualitas pelayanan pemustaka yang diberikan suatu perpustakaan menjadi tolok ukur manfaat tidaknya suatu perpustakaan bagi pemakainya.

\section{Menurut Purwono}

penelusuran informasi adalah kegiatan menelusur kembali seluruh atau sebagian informasi yang pernah ditulis atau diterbitkan melalui sarana temu kembali informasi yang tersedia. Strategi penelusuran adalah penelusuran yang dilakukan secara sistematis (systematic searching), yang meliputi cara-cara bagaimana menggunakan kata kunci (keyword), frase, subjek dokumen, menggunakan logika Boolean (Boolean logic) serta fasilitas-fasilitas penelusuran lain yang tersedia pada masing-masing search engines dan pangkalan data off line. Dengan strategi penelusuran ini diharapkan penelusur (user), bisa menemukan dokumen atau informasi yang diperlukan secara cepat dan tepat/relevan.

Kegiatan penelusuran informasi menurut Driani (2009) informasi yang ditelah ditemukan sebaiknya dievaluasi terlebih dahulu oleh pemustaka sehinggadapat diketahui secara pasti apakah informasi tersebut benar-benar sesuai dengan kebutuhan. Menurut Mawati dan Bakhtaruddin (2013) permasalahan dalam kualitas layanan di perpustakaan adalah masalah kemampuan pemustaka dalam penelusuran informasi Online Public Access Catalog(OPAC).

Cabrerizo, Morente-Molinera, Pérez, López-Gijón, and Herrera-Viedma (2015) menyatakan bahwa guna memenuhi harapan untuk membuat keputusan pengguna, sangat penting perpustakaan digital memberikan pelayanan yang baik dalam memenuhi kebutuhan penggunanya, meningkatkan jumlah penggunaserta meningkatkan kualitas layanan. Menurut Crawford (1993) dalam Michael and Elijah (2014) salah satu kebutuhan informasi seseorang tergantung pada kebutuhan untuk membuat keputusan dan kebutuhan mencari ide baru.

Menurut pernyataan Lancaster, faktor yang mempengaruhi pemanfaatan koleksi adalah ketersediaan subjek tertentu; jumlah koleksi, alat bantu temu kembali, dan faktor pekerjaan pemustaka serta kebutuhan informasi pemustaka (Harahap 2010).

Keputusan penelusuran informasi melalui OPAC tergantung kemampuan pemustaka dalam menelusur informasi serta mengevaluasi apakah informasi 
benar-benar sesuai dengan kebutuhannya. Perpustakaan harus memberikan pelayanan yang baik untuk meningkatkan kualitas layanan serta jumlah pemustaka supaya ketersediaan koleksi dan alat bantu temu kembali informasi bisa dimanfaatkan.

Untuk membantu pengguna menemukan koleksi informasi yang dibutuhkan, Perpustakaan Balittro menyediakan sarana temu kembali informasi berupa OPAC yang hanya memuat informasi bibliografis, dan sebagian sudah dilengkapi fulltext. Terkait dengan kegiatan penelusuran di Perpustakaan Balittro salah satu hal utama yang dilakukan oleh pemustaka untuk menemukan sumber-sumber literatur atau koleksi perpustakaan adalah dengan menelusur melalui fasilitas OPAC. OPAC di Perpustakaan Balittro tersebut terdiri dari pangkalan data buku, Informasi Pertanian Tanaman Rempah dan Obat (IPTANTRO), majalah yang hampir sebagian terdapat fulltext. OPAC tersebut merupakan sarana penelusuran pemustaka untuk mencari informasi yang dibutuhkan. Berdasarkan pernyataan Armadan Nelisa (2013) sebagai sarana penyedian informasi, perpustakaan dituntut untuk menyediakan berbagai macam informasi yang sesuai dengan kebutuhan pemakai dan sesuai dengan perkembangan ilmu pengetahuan. Perpustakaan adalah tempat pencarian dan pengumpulan informasi. Oleh sebab itu, perpustakaan semestinya harus menyediakan koleksi yang lengkap dan baru sesuai minat atau kebutuhan pemakai.

Menurut pernyataan Surachman (2010) OPAC merupakan alat penelusuran informasi yang bersifat elektronik dan digital yang dapat digunakan untuk menemukan informasi pustaka/koleksi baik dalam bentuk tercetak maupun elektronik/digital. Berdasarkan latar belakang dan penelitian terdahulu bahwa pada kenyataannya saat ini OPAC masih banyak digunakan hanya untuk keperluan temu kembali informasi pustaka terutama yang tercetak atau dengan kata lain fungsinya hanya sebagai pengganti katalog tercetak dan belum begitu banyak penelitian mengevaluasi tentang kegiatan pemustaka dalam penelusuran informasi yang diperlukan melalui OPAC.

Mengacu pada permasalahan di atas, hipotesis dalam penelitian ini yaitu untuk menguji hubungan antara pemustaka dengan bahan pustaka yang ditelusur. Apabila terdapat hubungan antara pemustaka dengan bahan pustaka yang ditelusur maka hipotesis terima $\left(\mathrm{H}_{1}\right)$ atau tolak $\mathrm{H}_{0}$. Tujuan dari hipotesis adalah untuk menetapkan suatu dasar sehingga dapat mengumpulkan bukti yang berupa data-data dalam menentukan keputusan apakah menolak atau menerima kebenaran dari pernyataan atau asumsi yang telah dibuat. Uji hipotesis juga dapat memberikan kepercayaan diri dalam pengambilan keputusan yang bersifat objektif.

Berdasarkan latar belakang, hasil penelitian terdahulu, dan pengamatan penulis lakukan, maka tujuan penelitian ini adalah untuk mengetahui: keputusan pemustaka dalam penelusuran informasi mengenai a) jenis bahan pustaka yang ditelusur; b) komoditas yang ditelusur; dan c) hubungan pemustaka dengan bahan pustaka yang ditelusur di Perpustakaan Balai Penelitian Tanaman Rempah dan Obat.

\section{METODE PENELITIAN}

Penelitian didesain menggunakan metode deskriptif kuantitatif, sedangkan 
variabel yang diamati yaitu pemustaka yang menelusur informasi; sumber informasi yang dibutuhkan pemustaka; subjek/komoditas yang diperlukan pemustaka, dan hubungan pemustaka dengan bahan pustaka yang ditelusur. Penelitian dilaksanakan pada bulan November - Desember 2017, dengan objekpenelitian diperoleh dari data hasil penelusuran responden pemustaka berupa formulir hasil penelusuran bahan pustaka di Perpustakaan Balai Penelitian Tanaman Rempah dan Obat tahun 2015-2017.

Adapun parameter yang dianalisis meliputi jenis pemustaka, sumber informasi yang diperlukan, dan komoditas/subjek yang ditelusur melalui proses pengolahan data menggunakan software SPSS (Statistic Package for the Social Science) versi 22.0. Data yang dikumpulkan selanjutnya dianalisis secara deskriptif dan analisis korelasi Spearman's rank untuk mengetahui hubungan pemustaka dengan kategori bahan pustaka yang diperlukan.

$$
\begin{aligned}
& \text { Rumus } r_{s} \\
& r_{s}=1-\frac{6 \sum d^{2}}{n\left(n^{2}-1\right)}
\end{aligned}
$$

Keterangan:

$r_{s}=$ koefisien korelasi Spearman's rank

$d=$ selisih rank antara $\mathrm{X}\left(\mathrm{R}_{\mathrm{x}}\right)$ dan $\mathrm{Y}\left(\mathrm{R}_{\mathrm{y}}\right)$

$n=$ banyaknya pasangan rank

\section{HASIL DAN PEMBAHASAN}

Kegiatan penelusuran informasi diawali dengan adanya kebutuhan informasi yang muncul dari dalam diri manusia dilakukan berbeda-beda tergantung dengan kepentingan masing-masing individu. Setelah kebutuhan informasi muncul dalam diri pemustaka selanjutnya melakukan penelusuran informasi (Setiawan, 2017).

Perpustakaan dikatakan berhasil apabila perpustakaan mampu memenuhi kebutuhan pemustakanya. Pemustaka yang berkunjung ke Perpustakaan Balittro terdiri dari peneliti, karyawan, mahasiswa, pelajar, petani, swasta dan umum yang datang langsung mencari informasi mengenai tanaman obat, rempah, tanaman atsiri, dan tanaman perkebunan. Sesuai dengan pernyataan Hasugian (2009) dalam Rizal dan Rahmah (2013) tujuan perpustakaan khusus adalah perpustakaan yang hanya menyediakan koleksi khusus yang berkaitan dengan misi dan tujuan dari organisasi atau lembaga yang memilikinya dan biasanya hanya memberikan pelayanan yang khusus hanya kepada staf organisasi atau lembaganya saja. Fungsi dan tujuan perpustakaan khusus sangat terkait bahkan ditentukan oleh organisasi induknya dan dibentuk untuk menyediakan informasi, baik berupa perkembangan iptek maupun informasi lain yang berkaitan dengan tugas dan fungsi organisasi induknya untuk para pegawai dan tenaga fungsionalnya.

Menurut pernyataan Siswoyo dalam Armadan Nelisa (2013) dalam spesifikasi pencarian informasi salah satunya terkandung unsure penyesuaian yang dapat berupa pengambilan keputusan untuk menghadapi situasi tertentu yang berkaitan dengan kebutuhan dan perilaku pencarian informasi. Selama kurun waktu 3 tahun terakhir jumlah pemustaka yang menelusur informasi di perpustakaan Balittro didominasi peneliti 317 (54,93\%), mahasiswa/pelajar 228 orang (39,52\%), dan umum/swasta 32 orang (5,55\%). Berdasarkan pengamatan penulis dan melayani pemustaka, Perpustakaan Balittro dalam kegiatan penelusuran informasi pemustakanya melakukan dengan dua cara yaitu a) menemui petugas/pustakawan dengan menjelaskan 
permasalahannya serta menelusur sendiri; dan b) menghubungi petugas/ pustakawan untuk meminta bantuan penelusuran dan mencarikan subjek yang relevan. Menurut Tjitro Panoto dalam Desmita dan Suryantini (2005) pemanfaatan perpustakaan mencakup pemanfaatan koleksi dan berbagai layanan yang tersedia di perpustakaan. Pemanfaatan koleksi perpustakaan bukan merupakan indikator pemanfaatan perpustakaan oleh peneliti, karena selain perpustakaan juga tersedia internet yang memudahkan peneliti untuk mengakses berbagai sumber informasi dengan cepat tanpa harus datang ke perpustakaan. Peneliti cenderung mencari informasi pada sumber informasi yang mudah dijangkau, koleksinya lengkap, layanannya baik, dan informasi yang disediakan mutakhir. Menurut Rushendi (2009) peneliti Balittro memanfaatkan publikasi sebagai bahan rujukan/referensi dalam kegiatan penelitian, dan sebaliknya juga sebagai wadah untuk menampung karya hasil-hasil penelitian yang telah dilakukan, menambah pengetahuan tentang hasil-hasil penelitian yang telah dilakukan oleh peneliti lain dan juga sebagai sarana komunikasi formal antara para peneliti (invisible college), juga untuk lembaga induknya. Selengkapnya presentase pemustaka yang menelusur informasi di Perpustakaan Balittro selama 3 tahun terakhir tersaji pada Tabel 1.

Menurut Nashihudin(2015) hal yang perlu diperhatikan pemustaka untuk menemukan informasi dengan mudah, cepat, dan tepat, diantaranya: a) menentukan sarana penelusuran; b) menentukan topik/subjek/kata kunci secara spesifik; c) mencatat kelengkapan data bibliografi koleksi, seperti judul, kode panggil, pengarang, tahun terbit/penerbit; d) menentukan jenis koleksi yang akan dibaca; dan e) jika tidak memahami cara penelusuran, segera meminta bantuan penelusuran kepada petugas.

Tabel 1

Presentase pemustaka yang menelusur informasi di perpustakaan Balittro 3 tahun terakhir

\begin{tabular}{lllllll}
\hline \multirow{2}{*}{ No } & \multirow{5}{*}{ User } & $\mathbf{2 0 1 5}$ & $\mathbf{2 0 1 6}$ & $\mathbf{2 0 1 7}$ & Jml & \% \\
\hline 1 & $\begin{array}{l}\text { Peneliti } \\
\text { Mhs/ }\end{array}$ & 84 & 160 & 73 & 317 & 54,93 \\
2 & $\begin{array}{l}\text { Pelajar } \\
\text { Unum }\end{array}$ & 99 & 66 & 63 & 228 & 39,52 \\
3 & $\begin{array}{l}\text { Umum } \\
\text { Swasta }\end{array}$ & 20 & 7 & 5 & 32 & 5,55 \\
\hline
\end{tabular}

Sumber: Hasil penelitian, 2017

Dilihat dari tujuan pemustaka, sebagian besar pemustaka Perpustakaan Balittro melakukan penelusuran literatur untuk tujuan penelitian yakni mencari sumber referensi/rujukan seperti koleksi buku (umum/referensi), jurnal ilmiah Indonesia/asing, makalah/prosiding, laporan penelitian, dan skripsi, tesis/disertasi, brosur, leaflet, sirkuler, dan lain lain berupa informasi tanaman rempah, obat, minyak atsiri, tanaman industri lainnya dan tanaman pestisida nabati. Sejalan dengan pernyataan Surachman kegiatan penelusuran informasi merupakan bagian dari kegiatan temu kembali informasi menggunakan sistem atau alat temu kembali sebagai sarana penelusuran informasi (Putra, 2017). Literatur-literatur tersebut dapat diakses melalui OPAC yang berisi informasi tentang database koleksi buku, IPTANTRO dan database majalah. Berdasarkan hasil penelitian Kusmayadi \& Andriaty (2006) OPAC sangat membantu pengguna mempercepat dan mempermudah menemukan literatur yang diperlukan, dan pengguna merasa nyaman dan puas menggunakannya. Jumlah database di Perpustakaan Balai Penelitian 
Tanaman Rempah dan Obat tersaji pada Tabel 2.

Tabel 2

Jumlah rekor pangkalan data di perpustakaan Balittro

\begin{tabular}{lll}
\hline No & Pangkalan data & Rekor \\
\hline 1 & Buku & 4.379 \\
2 & IPTANTRO & 18.917 \\
3 & Majalah & 94 \\
\hline
\end{tabular}

Sumber: Hasil penelitian, 2017

Sebagai pusat sumber informasi, perpustakaan berfungsi menyediakan berbagai sumber informasi untuk memenuhi kebutuhan pemustakanya. Sumber-sumber informasi yang disediakan tersedia dalam bentuk tercetak dan terekam. Dalam menjalankan fungsinya, perpustakaan melakukan kegiatan antara lain mengidentifikasi, memilih, mengadakan, mengatalog, dan memproses sumber-sumber informasi sehingga tersedia dan dapat ditemu-balik dan digunakan secara efisien. Sumber informasi yang diperlukan pemustaka di perpustakaan Balittro selama 3 tahun terakhir terbanyak mencari sumber informasi dokumentasi (laporan penelitian, prosiding, monograf, dll.)/ $52,51 \%$, diikuti sumber informasi jurnal 27,66\%, dan buku 19,83\%. Berdasarkan pengamatan di perpustakaan Balittro, hampir semua pemustaka mencari laporan penelitian dan prosiding untuk menyusun proposal, laporan akhir, serta laporan penelitian sebagai bahan acuan. Sejalan dengan hasil penelitian Ainurrohmah \& Prasetyawan (2016) informasi yang didapatkan dari hasil penelusuran pemustaka diolah hingga menghasilkan produk informasi baik berupa jurnal, buku dan prosiding. Selengkapnya sumber informasi yang diperlukan pemustaka perpustakaan Balittro selama 3 tahun terakhir tersaji pada Tabel 3.
Tabel 3

Sumber informasi yang diperlukan pemustaka 3 tahun terakhir

\begin{tabular}{llccrrl}
\hline \multirow{2}{*}{ No } & Bahan & \multicolumn{2}{l}{ Tahun } & & \multirow{2}{*}{ Jml } & \multirow{2}{*}{$\%$} \\
& Pustaka & $\mathbf{2 0 1 5}$ & $\mathbf{2 0 1 6}$ & $\mathbf{2 0 1 7}$ & & \\
\hline 1 & Buku & 112 & 155 & 65 & 332 & 19,83 \\
2 & Jurnal & 168 & 176 & 119 & 463 & 27,66 \\
3 & Doku & 319 & 365 & 195 & 879 & 52,51 \\
& mentasi* & & & & & \\
\hline
\end{tabular}

*Dokumentasi: prosiding, laporan penelitian, leaflet, brosur, dll.

Sumber: Hasil Penelitian, 2017

Perpustakaan Balittro merupakan perpustakaan khusus yang sebagian besar koleksinya bidang pertanian khusus tanaman obat, tanaman rempah, tanaman minyak atsiri, tanaman pestisida nabati dan tanaman perkebunan. Perpustakaan tersebut didirikan dan diperuntukan untuk menunjang kegiatan penelitian para peneliti, tidak terkecuali para mahasiswayang akan menyusun dan melaksanakan penelitian, pelajar, petani dan pengusaha yang membutuhkan informasi tanaman obat, rempah dan minyak atsiri, dll. (Rushendi, 2017). Sebagian besar subjek atau komoditas yang dibutuhkan pemustaka selama tahun 2015-2017 yaitu tanaman obat sebesar 266 pemustaka $(46,10 \%)$, tanaman rempah 154 (26,69\%), dan tanaman minyak atsiri 147 orang $(25,48 \%)$, sedangkan tanaman pestisida nabati hanya diakses pemustaka 10 orang $(1,73 \%)$. Berdasarkan pernyataan Santandreu \& Shurden permasalahan awal sebuah organisasi yang menyediakan produk/layanan harus mempertimbangkan kualitas kinerja pelayanan, keakuratan informasi sebagai faktor relevan menentukan bagi konsumen/pemustaka generasi baru. Subjek/komoditas yang dibutuhkan pemustaka tahun 2015-2017 tersaji pada Tabel 4. 
Tabel 4

Subjek/komoditasyang dibutuhkan pemustaka tahun 2015-2017

\begin{tabular}{|c|c|c|c|c|c|}
\hline \multirow[b]{2}{*}{ Komoditas } & \multicolumn{3}{|c|}{ Pemustaka } & \multirow[b]{2}{*}{ Jml } & \multirow[b]{2}{*}{$\%$} \\
\hline & $\begin{array}{l}\text { Pen } \\
\text { eliti }\end{array}$ & $\begin{array}{l}\text { Mhs/ } \\
\text { Pelajar }\end{array}$ & $\begin{array}{l}\text { Umum/ } \\
\text { Swasta }\end{array}$ & & \\
\hline Tanaman & & & & & \\
\hline Obat & 108 & 141 & 17 & 266 & 46,10 \\
\hline Tanaman & & & & & \\
\hline Rempah & 103 & 42 & 9 & 154 & 26,69 \\
\hline
\end{tabular}

Sumber: Hasil penelitian, 2017

Perpustakaan harus dapat memberi informasi kepada pemustaka, karena tujuan perpustakaan adalah memberi pelayanan supaya bahan pustaka yang telah dikumpulkan dan diolahdapat sampai ke tangan pemustaka. Bahan-bahan pustaka yang dikumpulkan selanjutnya diolahdan disajikan untuk mempermudah proses pencarian bahan pustaka sesuai yang dikehendaki pemustaka. (Hadi, Boham, \& Senduk, 2014).

Dalam memenuhi kebutuhan informasi pemustakanya, perpustakaan perlu memperhatikan ketersediaan bahan pustaka atau koleksi dengan kebutuhan informasi pemustaka yang datang ke perpustakaan tersebut. Kebutuhan informasi seseorang didorong oleh keadaan dalam diri seseorang dan perannya dalam lingkungannya. Dimana seseorang menyadari bahwa pengetahuan yang ia miliki masih kurang sehingga ada keinginan untuk memenuhi kebutuhan informasi. Informasi tersebut dapat digunakan untuk menambah pengetahuan mengenai lingkungan masyarakat, tugas-tugas pribadi sesuai dengan pekerjaan, pendidikan, hiburan dan untuk pengambilan keputusan (Fadhilah \& Nelisa, 2014). Menjawab tujuan dalam penelitian ini, maka penulis melakukan uji korelasi Spearman's rank untuk mengetahui hubungan pemustaka dengan bahan pustaka yang diperlukan, serta menguji hipotesis. Berdasarkan hasil uji korelasi didapat adanya hubungan antara pemustaka peneliti dengan bahan pustaka jurnal dan dokumentasi (laporan penelitian, prosiding, monograf, dll); adanya keterkaitan pemustaka mahasiswa dengan buku, jurnal dan dokumentasi; serta adanya hubungan pemustaka umum/swasta dengan buku dan dokumentasi (laporan penelitian, prosiding, monograf, dll). Selengkapnya hasil uji korelasi Spearman's rank tersaji pada Tabel 5, 6, dan 7.

Tabel 5

Koefisien korelasi Spearman's rank $\left(r_{s}\right)$ peneliti dengan kategori bahan pustaka yang diperlukan

\begin{tabular}{|c|c|c|c|c|}
\hline \multicolumn{2}{|c|}{ Koefisien korelasi } & Buku & $\begin{array}{l}\text { Jurn } \\
\text { al }\end{array}$ & $\begin{array}{l}\text { Dokum } \\
\text { entasi }\end{array}$ \\
\hline \multirow{3}{*}{ Peneliti } & $r_{s}$ & 1,000 & 0,185 & 0,233 \\
\hline & $\begin{array}{l}\text { Sig. } \\
\text { (2-tailed) }\end{array}$ & 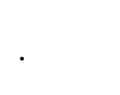 & $\begin{array}{l}0,001 \\
* *\end{array}$ & $0,000^{* *}$ \\
\hline & $\mathrm{N}$ & 317 & 317 & 317 \\
\hline
\end{tabular}

Pemustaka yang dominan yang berkunjung ke perpustakaan Balittro adalah peneliti lingkup Badan Penelitian dan Pengembangan Pertanian. Salah satu kegiatan perpustakaan Balittro yaitu menyediakan informasi yang diperlukan oleh peneliti untuk menunjang kegiatan penelitiannya.

Menjawab hipotesis penelitian maka dilakukan uji Spearman. Berdasarkan hasil analisis didapat bahwa terdapat hubungan signifikan pemustaka peneliti dengan bahan pustaka yang dibutuhkan yaitu jurnal dan dokumentasi sebesar < $1 \%$ dengan nilai koefisien korelasi 0,185 dan 0,233 , hal ini menunjukkan bahwa semakin banyak peneliti membutuhkan bahan pustaka jurnal dan dokumentasi/ 
laporan-laporan penelitian semakin berkualitas karya tulis ilmiah dan laporan penelitian. Berdasarkan hasil kajian Rushendi (2010) peneliti Balittro memanfaatkan jurnal untuk menemukan ide penelitian serta menyusun proposal penelitian dan laporan penelitan yang disusunnya. Hal ini diperkuat dengan hasil pengkajian Rufaidah, Maksum \& Suryantini (2011) bahwa peneliti dan penyuluh Badan Litbang Pertanian saat ini sangat membutuhkan 87 judul jurnaldan 71 judul dibutuhkan dari 650 judul jurnal yang tersedia. Subjek jurnal yang paling banyak dibutuhkan adalah sosial ekonomi pertanian.

Kunjungan mahasiswa ke perpustakaan disebabkan oleh adanya kebutuhan informasi yang mendorong mereka untuk memanfaatkan koleksi perpustakaan yang telah disediakan. Kebutuhan informasi yang melatarbelakangi mahasiswa dalam memanfaatkan koleksi perpustakaan dipengaruhi oleh dorongan muncul dari kondisi lingkungan perpustakaan dan cenderung muncul atas keinginan atau kebutuhan mahasiswa dalam mencapai sebuah tujuan yang harus dicapai. (Istiawan, 2015). Hasil uji korelasi Spearman's rankdidapat bahwa adanya hubungan nyata antara pemustaka mahasiswa dengan bahan pustaka buku dan dokumentasi sebesar <0,01 dengan nilai koefisien korelasi sebesar $11,3 \%$ dan $24,5 \%$, hal ini mengindikasikan bahwa mahasiswa memperoleh bahan pustaka buku dan dokumentasi untuk mendukung kegiatan tugas kuliah dan laporan penelitiannya. Berdasarkan pengamatan di lapangan bahwa sebagai langkah awal mahasiswa memanfaatkan koleksi perpustakaan Balittro untuk menyusun laporan/skripsinya dengan membutuhkan buku-buku dan laporan hasil penelitian. Senada dengan hasil penelitian Irianti (2014) bahwa tujuan pemanfaatan sumber informasi sebagian besar mahasiswa di Perpustakaan Fakultas Psikologi UGM yaitu untuk keperluan menyusun tugas akhir (skripsi, tesis, atau disertasi)dan penyusunan tugas mata kuliah denganjenis sumber informasi yang digunakan berupa buku teks, karya hasil penelitian (skripsi, tesis dan disertasi). Selengkapnya koefisiensi korelasi Spearman's rank pemustaka mahasiswa dengan kategori bahan pustaka yang diperlukan tersaji pada Tabel 6 .

Tabel 6

Koefisien korelasi Spearman's rank $\left(r_{s}\right)$ mahasiswa dengan kategori bahan pustaka yang diperlukan

\begin{tabular}{|c|c|c|c|c|}
\hline \multicolumn{2}{|c|}{$\begin{array}{l}\text { Koefisien } \\
\text { korelasi }\end{array}$} & \multirow{2}{*}{$\frac{\text { Buku }}{0,113}$} & \multirow{2}{*}{$\frac{\text { Jurnal }}{0,091}$} & \multirow{2}{*}{$\begin{array}{l}\text { Dokumentasi } \\
0,245\end{array}$} \\
\hline \multirow{3}{*}{ Mhs } & $r_{s}$ & & & \\
\hline & $\begin{array}{l}\text { Sig. } \\
\text { (2-tailed) }\end{array}$ & $0,007 * *$ & $0,028 *$ & $0,000 * *$ \\
\hline & $\mathrm{N}$ & 228 & 228 & 228 \\
\hline
\end{tabular}

* berhubungan nyata pada nilai signifikansi <0,05

** berhubungan nyata pada nilai signifikansi $<0,01$

Sumber: Hasil penelitian, 2017

Hubungan antara pengguna dan pengelola perpustakaan sangat erat terutama apabila dihubungkan dengan pemenuhan kebutuhan dan pengembangan perpustakaan itu sendiri. Tidak sedikit pemustaka akan ikut andil dalam menentukan pola pengelolaan dan juga penentuan koleksi/informasi yang perlu disediakan oleh perpustakaan Surachman (2005). Selengkapnya koefisiensi korelasi Spearman's rank swasta/umum dengan kategori bahan pustaka yang diperlukan tersaji pada Tabel 7. 
Tabel 7

Koefisien korelasi Spearman's rank $\left(r_{s}\right)$ umum/swasta dengan kategori bahan pustaka yang diperlukan

\begin{tabular}{lllll}
$\begin{array}{l}\text { Koefisien } \\
\text { korelasi }\end{array}$ & Buku & $\begin{array}{l}\text { Jurn } \\
\text { al }\end{array}$ & $\begin{array}{l}\text { Dokument } \\
\text { asi }\end{array}$ \\
\hline Umum & $r_{s}$ & 0,113 & 0,091 & 0,245 \\
Sig. & $0,007^{*}$ & 0,028 & $0,000^{* *}$ \\
Swasta & $\begin{array}{l}\text { (2-taile } \\
\text { d) }\end{array}$ & $*$ & $*$ & \\
& $\mathrm{~N}$ & 228 & 228 & 228 \\
\hline
\end{tabular}

** berhubungan nyata pada nilai signifikansi < 0,01

Sumber: Hasil penelitian, 2017

Hasil analisis korelasi Spearman's rank didapat bahwa terdapat hubungan nyata variabel $X$ (pemustaka umum/swasta) dengan variabel $\mathrm{Y}$ (bahan pustaka buku dan dokumentasi) sebesar $<a 1 \%$ dengan nilai koefisien korelasi sebesar 0,226 dan 0,380, ini berarti bahwa pemustaka umum/swasta memerlukan bahan pustaka berupa petunjuk teknis, sirkuler, brosur dan leaflet perkomoditas sebagai bahan mereka untuk memulai dan mengembangkan pertaniannya. Sesuai dengan pernyataan Ruyadi, Winoto, dan Komariah (2017) dalam upaya mengkomunikasikan informasi hasil penelitian teknologi pertanian, Badan Penelitian dan Pengembangan Pertanian menerbitkan berbagai jenis media komunikasi dan informasi pertanian seperti brosur dan leaflet karena materinya relevan, informasinya mutahir dan akurat. Perpustakaan khusus dalam pengelolaan sangat disesuaikan dengan kebutuhan dan karakteristik pemustakanya.

\section{SIMPULAN}

Kegiatan penelusuran informasi yang diperlukan pemustaka melalui fasilitas OPAC yang dominan menelusur informasiyaitu pemustaka peneliti, dengan sumber informasi yang diperlukan mencari bahan pustaka dokumentasi (laporan penelitian, prosiding, monograf, dll), dan sebagian besar pemustaka mencari subjek/komoditas yang diperlukan yaitu tanaman obat. Terdapat hubungan pemustaka peneliti dengan keputusan penelusuran bahan pustaka jurnal dan dokumentasi; terdapat hubungan pemustaka mahasiswa dengan keputusan penelusuran bahan pustaka buku, jurnal dan dokumentasi; serta terdapat korelasi pemustaka umum/swasta dengan keputusan penelusuran buku dan dokumentasi.

Pelayanan penelusuran informasi di Perpustakaan Balittro perlu ditingkatkan dengan menghubungkan basis data penelusuran online dengan website Balittro sehingga bisa bertambah jumlah koleksi onlinenya.

\section{DAFTAR PUSTAKA}

Arma, M.A., \& Nelisa, M. (2013). Perilaku pencarian informasi pemustaka. Jurnal Ilmu Informasi Perpustakaan dan Kearsipan, 1(2), 16-23.

Cabrerizo, F. J., Morente-Molinera, J. A., Pérez, I. J., López-Gijón, J., \& Herrera-Viedma, E. (2015). A decision support system to develop a quality management in academic digital libraries. Information Sciences, 323(C), 48-58.

Driani, M. (2009). Penelusuran informasi siswa melalui internet: studi kasus di Perpustakaan MAN Insan Cendekia Serpong. Jakarta: Ilmu Perpustakaan UIN Syarif Hidayatullah.

Fransisca, D. (2013). Motivasi kunjungan pada perpustakaan umum (studi deskriptif mengenai motivasi kunjungan pada perpustakaan umum kota trenggalek). Journal Universitas Airlangga, 2(2), 1-13. 
Harahap, I.E. 2010. Hubungan ketersediaan koleksi dengan penggunaan koleksi pada perpustakaan Universitas Negeri Padang. Medan: Program Studi Perpustakaan dan Informasi USU. Jurnalista, A.M.F., \& Hermintoyo. (2016). Layanan gerobak buku sebagai rekreatif bagi pemustaka Perpustakaan Bank Indonesia Semarang. Jurnal Ilmu Perpustakaan, 5(1), 321-330.

Mawati, Y., \& Bakhtaruddin, N.S.T. (2013). Pemanfaatan online public access catalogue (OPAC) untuk meningkatkan kualitas layanan di perpustakaan universitas negeri padang. Jurnal Ilmu Informasi Perpustakaan dan Kearsipan,2(1), 435-442.

Michael, E., \& Elijah, P. (2014). Information literacy skills and information use by students in two south university libraries in Nigeria. International Journal of Economics, Commerce and Management, 2(9), 1-16.

Nashihuddin, W. (2015). Pemahaman pemustaka dalam menelusur sumber-sumber literatur di Perpustakaan PDII-LIPI. Jurnal Pustakawan Indonesia,13(2), 28-39.

Perpusnas. (2015). Peraturan kepala perpustakaan nasional republik indonesia no. 11 tahun 2015 tentang petunjuk teknis jabatan fungsional pustakawan dan angka kreditnya. Jakarta: Perpusnas.

Purwono. (2008). Strategi penelusuran informasi melalui internet. Desember 26 , 2016.

http:/ / eprints.rclis.org/12193/

Putra, F. E. (2017). Kegiatan layanan dalam penelusuran informasi di perpustakaan. Iqra': Jurnal Perpustakaan dan Informasi, 11(1), 48-65.
Rasdanelis. (2016). Perpustakaan sebagai lembaga pendidikan informal dalam sejarah pendidikan islam. Jurnal Ilmiah Kepustakawanan Libraria, 5(2), 91-110.

Riadi, M. (2012). Pengertian, jenis dan tujuan perpustakaan. Desember 30, 2016.http:/ / www.kajianpustaka. com

Rizal, A., \& Rahmah, E. (2013). Penggelolaan bahan pustaka di perpustakaan kantor camat Koto XI Tarusan kabupaten Pesisir Selatan. Jurnal Ilmu Informasi Perpustakaan dan Kearsipan, 2(1), 504-510.

Rushendi. (2009). Kontribusi karya tulis hasil penelitian dalam buletin penelitian tanaman rempah dan obat. Jurnal Perpustakaan Pertanian, 18(1), 24-28.

Rushendi. (2010). Persepsi peneliti balai penelitian tanaman obat dan aromatik terhadap jurnal elektronik. Jurnal Perpustakaan Pertanian, 19(2), 58-65.

Rushendi. (2017). Pengaruh penelitian tingkat peneliti terhadap karya tulis ilmiah peneliti balai penelitian tanaman rempah dan obat. Prosiding Temu Teknis Non Peneliti Balitbang Pertanian, Jakarta 6-7 September 2017. IAARD Press. $13 \mathrm{hlm}$.

Ruyadi I., Winoto, Y. \& Kormariah, N. (2017). Media komunikasi dan informasi dalam menunjang kegiatan penyuluhan pertanian. Jurnal Kajian Informasi dan Perpustakaan,5(1), 35-48.

Setiawan, M. V. (2017). Mengurangi kecemasan pemustaka dalam proses penelusuran informasi melalui layanan virtual referens di perpustakaan perguruan tinggi. Berkala Ilmu Perpustakaan dan Informasi, 13(2), 178. 
Lampiran 1.

\section{FORMULIR PENELUSURAN BAHAN PUSTAKA \\ PERPUSTAKAAN BALAI PENELITIAN TANAMAN REMPAH DAN OBAT}

Nama Pengguna

Pekerjaan

Koleksi yang dipesan

: Judul Buku/Majalah/Jurnal/Prosiding

1.

2.

3

4

5

Komoditas

Subjek

Bogor, $20 \ldots$

Pustakawan

Pemustaka,

NIP.

BON PEMINJAMANBAHAN PUSTAKA PERPUSTAKAAN BALAI PENELITIAN TANAMAN REMPAH DAN OBAT

Peminjam

Alamat/Kelti

Judul Buku/majalah

$: 1$.

2 .

3.

4.

5.

Pengarang

Dikembalikan Tanggal:

Diperpanjang s/d Tanggal:

Bogor, ............... 20...

Pustakawan

Peminjam,

NIP. 
